\title{
Cross-Protection as Control Strategy Against Grapevine fanleaf virus in Naturally Infected Vineyards
}

Véronique Komar, Emmanuelle Vigne, Gérard Demangeat, and Olivier Lemaire, Institut National de la Recherche Agronomique and Université Louis Pasteur de Strasbourg, UMR 1131, Unité Mixte de Recherche Santé de la Vigne et Qualité du Vin, BP 20507, 68021 Colmar, France; and Marc Fuchs, Institut National de la Recherche Agronomique and Université Louis Pasteur de Strasbourg, and Department of Pathology and Plant-Microbe Biology, Cornell University, New York State Agricultural Experiment Station, Geneva, NY 14456, USA

\begin{abstract}
Komar, V., Vigne, E., Demangeat, G., Lemaire, O., and Fuchs, M. 2008. Cross-protection as control strategy against Grapevine fanleaf virus in naturally infected vineyards. Plant Dis. 92:1689-1694.

The efficacy of cross-protection at mitigating the impact of Grapevine fanleaf virus (GFLV) on grapevines (Vitis vinifera) was assessed in two naturally infected vineyard sites. Test vines consisted of scions grafted onto rootstocks that were healthy or infected by mild protective strains GFLV-GHu or Arabis mosaic virus (ArMV)-Ta. Challenge GFLV infection via the nematode Xiphinema index was monitored over nine consecutive years in control and ArMV-Ta crossprotected vines by double-antibody sandwich-enzyme-linked immunosorbent assay using GFLV-specific antibodies, and in GFLV-GHu cross-protected vines by characterizing the coat protein gene of superinfecting isolates by immunocapture-reverse transcription-polymerase chain reaction-restriction fragment length polymorphism. Results were consistent with a significantly reduced challenge infection rate in cross-protected vines compared with control vines, more so in those protected with GFLV-GHu (19 versus 90\%) than with ArMV-Ta (40 versus $65 \%$ in field A and 63 versus $90 \%$ in field B). However, the two mild strains significantly reduced fruit yield by 9\% (ArMV-Ta) and 17\% (GFLV-GHu) over 8 years and had a limited effect on fruit quality. Therefore, in spite of a great potential at reducing the incidence of challenge field isolates, cross-protection with natural mild protective strains GFLV-GHu and ArMV-Ta is not attractive to control GFLV because the negative impact on yield is a limiting factor for its deployment.
\end{abstract}

Grapevine fanleaf virus (GFLV) is responsible for fanleaf degeneration, the most severe virus disease of grapevines (1). This virus is present in the majority of vineyards where Vitis vinifera grapes and French-American rootstocks are grown. GFLV reduces plant vigor and the productive lifespan of vineyards. It also incites severe yield losses (up to 80\%) and alters fruit quality (1). GFLV is transmitted from vine to vine by the ectoparasitic nematode Xiphinema index.

Control strategies against GFLV in infected vineyards are essentially directed against its nematode vector (1). Roguing of GFLV-infected vines can limit the spread of the disease, and soil disinfection with nematicides prior to planting can reduce $X$. index populations. These strategies are of limited efficacy because viruliferous $X$. index can survive in infested soils over extended periods of time even in the absence of any host plant

Corresponding author: M. Fuchs

E-mail: mf13@cornell.edu

Accepted for publication 8 September 2008.

doi:10.1094/PDIS-92-12-1689

(C) 2008 The American Phytopathological Society
$(1,10)$. Rootstocks with resistance to $X$. index feeding have been developed, but they do not prevent GFLV spread into scions $(1,38)$. Therefore, there is a need to develop alternative approaches to mitigate the impact of GFLV (1).

Cross-protection has been explored as a biological strategy to manage plant viruses $(8,14,19,20,25,27)$. This phenomenon relies on the use of mild virus strains to protect plants from economic damage caused by severe virus strains $(14,20,25)$. The mechanism of cross-protection is not well characterized, although competition for host factors, differential spatial distribution of distinct viruses and virus strains with regard to exclusion mechanisms $(12,16,25,28)$, and post-transcriptional gene silencing (PTGS) in terms of RNAmediated resistance $(26,43)$ have been suggested.

Mild isolates of GFLV and Arabis mosaic virus (ArMV), a closely related nepovirus (11), were identified by comparative performance analysis of grapevines infected with different strains (22) and by comparative symptom severity screening on Chenopodium quinoa, a systemic herbaceous host for both viruses. The successful use of the mild strains GHu of GFLV and Ta of ArMV to protect plants from challenge infection with severe
GFLV strains was shown in $C$. quinoa (17). Protection with mild GFLV strains against GFLV infection was also achieved in Gomphrena globosa (6). These earlier results suggested that cross-protection with mild strains of GFLV and ArMV could be effective to protect grapevines from GFLV infection. To validate data obtained in herbaceous plants, we assessed the protective ability of mild strains GFLV-GHu and ArMV-Ta in two naturally GFLV-infected vineyard sites. We report here on the potential of these two mild protective viral strains at reducing the rate of GFLV challenge infection and at mitigating the impact of GFLV on fruit yield and quality.

\section{MATERIALS AND METHODS}

Mild protective virus strains. Strains GHu of GFLV (17) and Ta of ArMV (21) were used as protective strains based on mild symptoms in C. quinoa (17) and limited impact on grape vigor and yield (22), respectively, in comparison with more severe viral strains. These two viral strains were propagated in C. quinoa and transferred onto the certified rootstock Kober 5BB (Vitis berlandieri $\times V$. riparia) clone 259 by in vitro heterologous grafting (4).

Plant material. Test plants consisted of certified $V$. vinifera cv. Gewurztraminer clone 643 grafted onto rootstock Kober 5BB clone 259. Graft-indexing on selective Vitis sp. indicators and doubleantibody sandwich (DAS) enzyme-linked immunosorbent assay (ELISA) were used to ascertain the sanitary status of the test material (18). At the beginning of the cross-protection field experiments, rootstocks were either healthy or infected by GFLV-GHu or ArMV-Ta.

Field sites and experimental layout. Areas of homogeneous topographic and soil conditions were selected for field trials in two naturally GFLV-infected commercial vineyards, one in Ammerschwihr (field A) and the other in Bennwihr (field B), two localities $15 \mathrm{~km}$ apart in the Alsace region of France. The presence of GFLV and its nematode vector $X$. index were both confirmed in the two experimental vineyard sites prior to planting. However, ArMV and its nematode vector $X$. diversicaudatum (17) were not found in the two vineyard sites. No soil disinfection was done with nematicides after uprooting 
established vines in fall 1992 in field A and in fall 1994 in field $\mathrm{B}$, because one of the objectives of the field experiments was to determine the reaction of test vines to natural transmission of GFLV by its nematode vector.

In field A, 112 healthy vines and 48 cross-protected vines infected with ArMVTa were planted in June 1993, making a total of 168 plants, including eight border plants on one side of the experimental site. Both treatments (healthy vines and crossprotected vines infected with ArMV-Ta) were assigned to two blocks in a split plot design. Each block had 80 plants, 56 healthy and 24 cross-protected, in 14 and 6 groups of four plants each, respectively, that were randomized within each block. Vines were planted in four rows of 40 plants each, spaced $1 \mathrm{~m}$ apart within rows and $2 \mathrm{~m}$ between rows.

In field B, 100 vines were planted in August 1995 for each of the three treatments (healthy vines, GFLV-GHu crossprotected vines, and ArMV-Ta crossprotected vines), making a total of 300 (3 $\times 100)$ plants. Treatments were assigned to two blocks in a split plot design. Each block had 150 plants, 50 per treatment, in 10 groups of five plants each randomized within each block. Vines were planted in five rows of 60 plants each, with the same spacing as in field $\mathrm{A}$.

The location of vines in fields $\mathrm{A}$ and $\mathrm{B}$ was identified by coordinates $\mathrm{x} . \mathrm{y}$, with $\mathrm{x}$ being the row number and $y$ the position within row $\mathrm{x}$. For example, vine 1.13 was in position 13 within row 1 .

Monitoring virus infection in test plants over time. The presence of GFLV was assessed by visually monitoring symptom development, i.e., foliar mosaic, deformation, vein chlorosis, plant stunting,

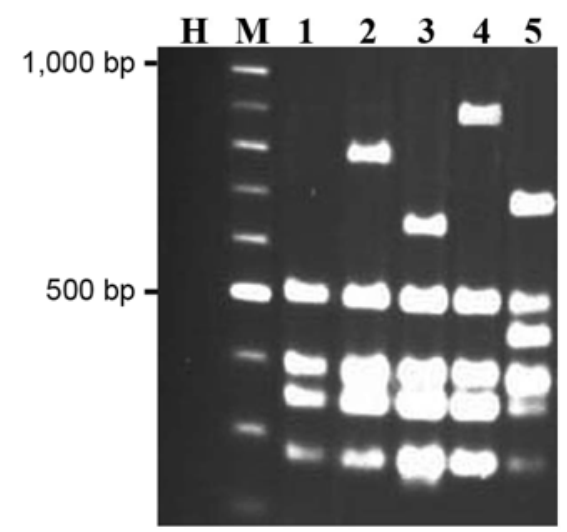

Fig. 1. StyI polymorphism characterization of the coat protein gene of Grapevine fanleaf virus (GFLV) isolates from the Bennwihr site by immunocapture-reverse transcription-polymerase chain reaction-restriction fragment length polymorphism. Lane 1: unchallenged GFLVGHu in vine 4.8; lanes 2 to 5: GFLV-GHu and field GFLV isolates in challenged vines 2.35, 4.7, 4.11, and 5.47, respectively; lane $\mathrm{H}$ : healthy vines; lane M: 100-bp DNA size standard (Promega). and short internodes (1). The virus was also monitored in samples of apical leaves of each test plant (five to six leaves per plant) for which the rootstock was initially healthy or infected by ArMV-Ta by DASELISA with anti-GFLV immunoglobulins produced in our laboratory (18). Serological tests were performed from 1998 to 2006 in the two vineyard sites in the spring (June). Samples were considered positive if their optical density $\left(\mathrm{OD}_{405 \mathrm{~nm}}\right)$ readings were at least twice those of healthy controls $\pm 20 \%$.

An immunocapture-reverse transcription-polymerase chain reaction-restriction fragment length polymorphism (IC-RTPCR-RFLP) assay with StyI was developed to differentiate the coat protein $(\mathrm{CP})$ gene of protective GFLV strain GHu and challenge field GFLV isolates, as described previously $(31,33)$. It was used to monitor GFLV infection in plants initially infected with GFLV-GHu in field B in 2004 and 2006.

In parallel to GFLV tests, the presence of ArMV-Ta was assayed in fields A and B on a yearly basis by DAS-ELISA using anti-ArMV immunoglobulins produced in our laboratory. Infected samples were identified as described above for GFLV.

Genetic variability of the $C P$ gene of mild protective virus isolates. The $\mathrm{CP}$ gene of mild strains GFLV-GHu and ArMV-Ta was characterized by IC-RTPCR. DNA amplicons were subsequently cloned into plasmid pGEM-3Zf(+) and sequenced, as described previously $(31,33)$. Nucleotide sequences were analyzed with the VectorNTI software package. The program CLUSTAL W was used for alignment of nucleotide sequences (30).

Analysis of fruit yield and quality. The number of clusters was counted at harvest in field B for each group of five plants per treatment, and clusters were weighted. In addition, berry samples were randomly collected for each group of five plants per treatment and crushed with a hand press to measure sugar content with a hand temperature-compensating refractometer and to evaluate titratable acidity by titration with $0.1 \mathrm{~N} \mathrm{NaOH}$ to $\mathrm{pH}$ 7.0. Data on fresh fruit yield, cluster number, and fruit maturity indices were analyzed from 1999 to 2006.

Statistical analyses. Data collected on virus infection of test plants, fruit yield, and fruit quality were summarized to obtain descriptive statistical parameters. Analysis of variance was used to detect treatment (cross-protected versus controls) differences and relationship between variables with SAS (Statistical Analysis System, SAS Institute Inc., Raleigh, NC). Disease progress was analyzed using a generalized linear model with a logit link function $\eta_{i}=\log \left(\hat{y}_{i} / 1-\hat{y}_{i}\right)$ where $\eta_{i}$ is modeled as $\eta_{i}=t_{i}^{T} \beta$ with $\hat{y}_{i}$ being the expected proportions showing infection and having uncorrelated binomial errors. The $\beta$ are treatment effects (parameters) and the $t_{i}$ are rows of the design matrix (explanatory variates). For variables related to fruit yield and quality, a mixed effect repeated measurements model was fitted with treatment (cross-protected versus control) and time as fixed effects and random experimental units. Contrasts among treatments using the means least squares (LS) method were used to compare differential effects on field performance due to mild protective virus isolates.

\section{RESULTS}

Characterization of the StyI CP gene polymorphism of GFLV-GHu and field GFLV isolates. An IC-RT-PCR-RFLP assay was developed to characterize the $\mathrm{CP}$ gene of mild protective strain $\mathrm{GHu}$ of GFLV and challenge field GFLV isolates. This molecular assay was necessary to determine the rate of superinfection of vines initially protected with GFLV-GHu because anti-GFLV immunoglobulins used in DAS-ELISA did not discriminate GFLV-GHu and field GFLV isolates (data not shown).

The 1.5-kb CP gene of GFLV-GHu (GenBank accession no. AY371026) digested with StyI generated five fragments of 510, 394, 350, 279, and 43 bp (Fig. 1, lane 1). The smallest fragment is not visible in Figure 1 but is deduced from in silico sequence analysis. Some field GFLV isolates from GFLV-GHu cross-protected vines had a more complex polymorphism (Fig. 1, lanes 2 to 5). For example, the banding pattern of isolate 2.35 (Fig. 1, lane 2) consisted of a 790-bp StyI fragment in addition to those typical of GFLV-GHu. Also, the CP gene of isolate 5.47 (Fig. 1, lane 5) had StyI fragments of 680, 450, and $380 \mathrm{bp}$ in addition to those of GFLV-GHu. The StyI CP gene polymorphism was further used to assess the rate of GFLV challenge infection in cross-protected vines initially infected with GFLV-GHu.

Effect of cross-protection on the rate of challenge GFLV infection. Crossprotection trials were established in 1992 and 1994 in two naturally GFLV-infected vineyard sites. Infection of test vines following $X$. index-mediated GFLV inoculation was monitored over time. Symptom development was used early on as an indicator of disease progress and severity. However, this approach was not sufficiently reliable to discriminate mild symptoms in cross-protected vines and discrete symptoms in control vines at an early infection stage. Therefore, starting in 1998, the rate of GFLV infection was monitored on a yearly basis by DAS-ELISA in vines initially infected with ArMV-Ta in fields A and B, and by IC-RT-PCR-RFLP in vines initially infected with GFLV-GHu in field B.

The percentage of infected plants increased over a 9-year period (1998 to 2006) (Fig. 2). GFLV incidence was generally lower in field A (65\% infected con- 
trol vines) than in field B (90\% infected controls) (Fig. 2), with odds of infection being half $(0.5 \pm 0.09)$ in field A relative to field B. However, regardless of vineyard site, the cumulative infection rate was reduced in cross-protected vines compared to control vines. In field A, a 40\% (19 of 48 plants) infection rate was obtained in vines preinoculated with ArMV-Ta while $65 \%$ (70 of 108 plants) of the controls were infected in 2006 (Fig. 2A). Similarly, in field $\mathrm{B}$, vines cross-protected with GFLV-GHu (19\%, 19 of 100 plants) and ArMV-Ta (63\%, 63 of 100 plants) had a reduced infection rate relative to control vines (90\%, 90 of 100 plants) (Fig. 2B). ANOVA indicated no significant field $x$ treatment (cross protection) interaction $(F$ $=0.002 ; \mathrm{df}=352 ; P=0.96$ ). Most of the variation detected was due to the main effect of cross-protection $(F=31.26$; $\mathrm{df}=$ 353; $P<0.0001)$, and to a lesser extent, to field site $(F=7.003 ; \mathrm{df}=354 ; P=$ 0.0085), confirming the beneficial impact of cross-protected vines at reducing the rate of challenge infection.

Odds of GFLV infection were quantitatively $2.5 \pm 0.42$ times greater for control than for ArMV-Ta-treated vines with 2.51 and 0.54 as coefficients fitted by the model for treatment [log-odds ratios = $\exp (0.922)]$ and field site [log-odds ratios $=\exp (-0.6169)]$, respectively. In addition, in field A, $29 \%$ of the controls were infected with GFLV in 1999, and this percentage doubled by 2003 (60\%), while only $31 \%$ of ArMV-Ta cross-protected vines were infected by GFLV in 2003 (Fig. $2 \mathrm{~A})$. In field $\mathrm{B}, 53 \%$ of the control vines were infected with GFLV in 2000 and $84 \%$ in 2004, while only $52 \%$ of the ArMV-Ta cross-protected vines were infected by GFLV in 2004 (Fig. 2B). Since a similar infection rate was achieved with a 4-year lapse in control versus ArMV-Ta crossprotected vines, cross-protection delayed GFLV infection by 4 years.

Effect of cross-protected vines on fruit yield. A comparative fruit yield analysis in field $\mathrm{B}$ indicated that cross-protected vines had a marked negative impact relative to control vines from 1999 to 2001, and to a lesser extent, in 2004, causing a 5 to $60 \%$ reduction (Fig. 3A). In 2002 to 2003 and 2005 to 2006, a positive or neutral impact on yield was observed in cross-protected vines (Fig. 3A). These data are likely explained by the fact that cross-protected vines were infected prior to the start of the field trial, hence yield was reduced early in the experiment. In contrast, control vines were infected gradually after planting, depending on the effectiveness of nematode-mediated GFLV transmission. ANOVA revealed a significant treatment $\times$ year interaction $(F=14$; df $=48 ; P<0.0001)$. Over 8 years (1999 to 2006), ArMV-Ta and GFLV-GHu induced an overall 9 and $17 \%$ yield reduction relative to control vines (Table 1). Differences in yield between
GFLV-GHu cross-protected and control vines $(t$ value $=-5.03 ; \mathrm{df}=48 ; P<$ $0.0001)$ and between ArMV-Ta crossprotected and control vines $(t$ value $=$ $-2.81 ; \mathrm{df}=48 ; P=0.0071)$ were significant, confirming that cross-protected vines depressed fruit production.

The number of clusters per vine was higher overall for cross-protected compared to control vines from 1999 to 2006 (Table 1). ANOVA revealed a significant treatment $\times$ year interaction $(F=5.27$; $\mathrm{df}=$ 48; $P<0.0001)$ with most of the variation due to year $(F=25.36$; df $=48 ; P<$
$0.0001)$ rather than cross-protection $(F=$ 1.78; df $=48 ; P=0.180)$. Differences of LS means between ArMV cross-protected and control vines $(t$ value $=1.73$; $\mathrm{df}=48$; $P=0.0894)$ and between GFLV-GHu cross-protected and control vines $(t$ value $=$ $1.51 ; \mathrm{df}=48 ; P=0.1382)$ were not significant. These data indicated that crossprotected vines had no impact on production in terms of cluster number.

Overall, the mean cluster weight was lower for cross-protected than for control vines throughout the cross-protection trial, except for ArMV-Ta cross-protected vines

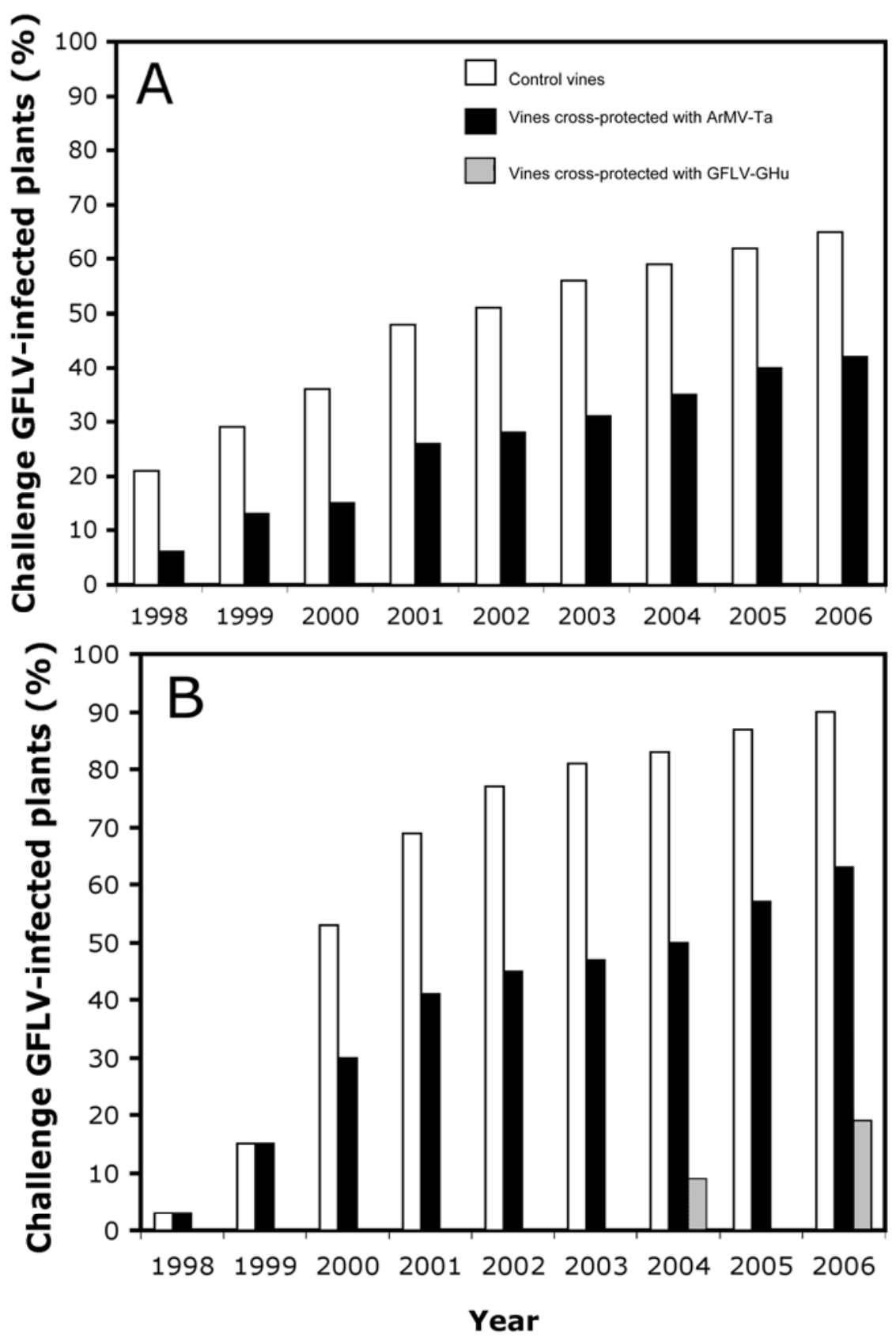

Fig. 2. Disease progress from 1998 to 2006 in cross-protected and control vines in naturally Grapevine fanleaf virus (GFLV)-infected vineyard sites in A, Ammerschwihr and $\mathbf{B}$, Bennwihr in the Alsace region in France. The presence of GFLV in control and cross-protected vines infected with Arabis mosaic virus (ArMV)-Ta was determined by double-antibody sandwich-enzyme-linked immunosorbent assay with anti-GFLV immunoglobulins, and in cross-protected vines infected with GFLV-GHu by immunocapture-reverse transcription-polymerase chain reaction-restriction fragment length polymorphism. 
in 2005 and 2006 (Fig. 3B). Vines initially infected with GFLV-GHu had a cumulative $20 \%$ reduction in cluster weight from 1999 to 2006, and those infected with ArMV-Ta showed a $14 \%$ reduction (Table 1). ANOVA indicated a significant treatment $x$ year interaction $(F=21.49$; df $=48 ; P<$ $0.0001)$. The variation observed was due to the combined effect of year $(F=73.30$; df $=48 ; P<0.0001)$ and cross-protection $(F$ $=28.31 ; \mathrm{df}=48 ; P<0.001)$. Differences in LS means between ArMV-Ta crossprotected and control vines were significant $(t$ value $=-5.16 ; \mathrm{df}=48 ; P<0.0001)$ as well as between GFLV-GHu crossprotected and control vines $(t$ value $=$ -7.32; df $=48 ; P<0.0001)$. Together, cross-protected vines had a negative impact on cluster weight. Since the number of clusters per vine was not affected, our data are consistent with smaller clusters in cross-protected relative to control vines.

Effect of cross-protected vines on fruit quality. Sugar content and titratable acidity in fruit juice were measured from 1999 to 2006 in field B as indicative of fruit quality. An overall increase in sugar level was observed in berries of cross-protected vines compared to control vines, although there were yearly fluctuations (Fig. 3C). Vines cross-protected with ArMV-Ta had a cumulative $2 \%$ increase in sugar content, and those initially infected with GFLVGHu had a 3\% increase (Table 1). ANOVA revealed a treatment $\times$ year interaction $(F$ $=5.80 ; \mathrm{df}=48 ; P<0.0001)$. Most of the variation observed in sugar content was due to year $(F=70.32$; df $=48 ; P<$ $0.0001)$ and, to a lesser extent, to crossprotection $(F=6.56$; df $=48 ; P<0.003)$. Differences in LS means between GFLV$\mathrm{GHu}$ cross-protected and control vines $(t$ value $=3.59 ; \mathrm{df}=48 ; P=0.0008)$ were significant, but those between ArMV-Ta cross-protected and control vines ( $F=$ 2.24; $\mathrm{df}=48 ; P=0.0297$ ) were not. These data indicated that cross-protected vines had limited, if any, impact on sugar content in fruit juice.

Titratable acidity fluctuated greatly from year to year (Fig. 3D). Vines crossprotected with ArMV-Ta had increased acidity values compared to controls for half of the data points $(1999,2002,2005$, and 2006), while GFLV-GHu crossprotected vines had decreased acidity values for most years, except 2002. ANOVA revealed no significant treatment $\times$ year interaction $(F=1.54 ; \mathrm{df}=48 ; P=0.1334)$, with most of the variation due to year $(F=$ 279.28; $\mathrm{df}=48 ; P<0.0001)$ but not to cross-protection $(F=1.01$; df $=48 ; P=$ $0.3720)$. Over time, the impact of cross-

Table 1. Cumulative effect of mild protective virus strains on fruit yield and quality of grapevines in a naturally Grapevine fanleaf virus (GFLV)-infected vineyard site in Bennwihr from 1999 to 2006

\begin{tabular}{lrccccc}
\hline \multirow{2}{*}{$\begin{array}{l}\text { Cross-protective } \\
\text { viral strain }^{\mathbf{b}}\end{array}$} & $\mathbf{N}$ & \multicolumn{5}{c}{ Impact on fruit yield and quality $^{\mathbf{a}}$} \\
\cline { 3 - 7 } & Yield (kg/vine) & No. cluster/vine & Weight/cluster & Sugar & Acidity \\
\hline ArMV-Ta & 100 & $-9^{* *}$ & +5 & $-14^{* *}$ & +2 & 0 \\
GFLV-GHu & 100 & $-17^{* *}$ & +4 & $-20^{* *}$ & $+3^{*}$ & -3 \\
\hline
\end{tabular}

${ }^{a}$ Percent increase $(+)$ or decrease $(-)$ relative to mean values of control vines. Significant differences of least squares means are indicated $(*=P<0.05 ; * *=P<0.0001) . \mathrm{N}=$ number of vines tested.

b ArMV = Arabis mosaic virus.
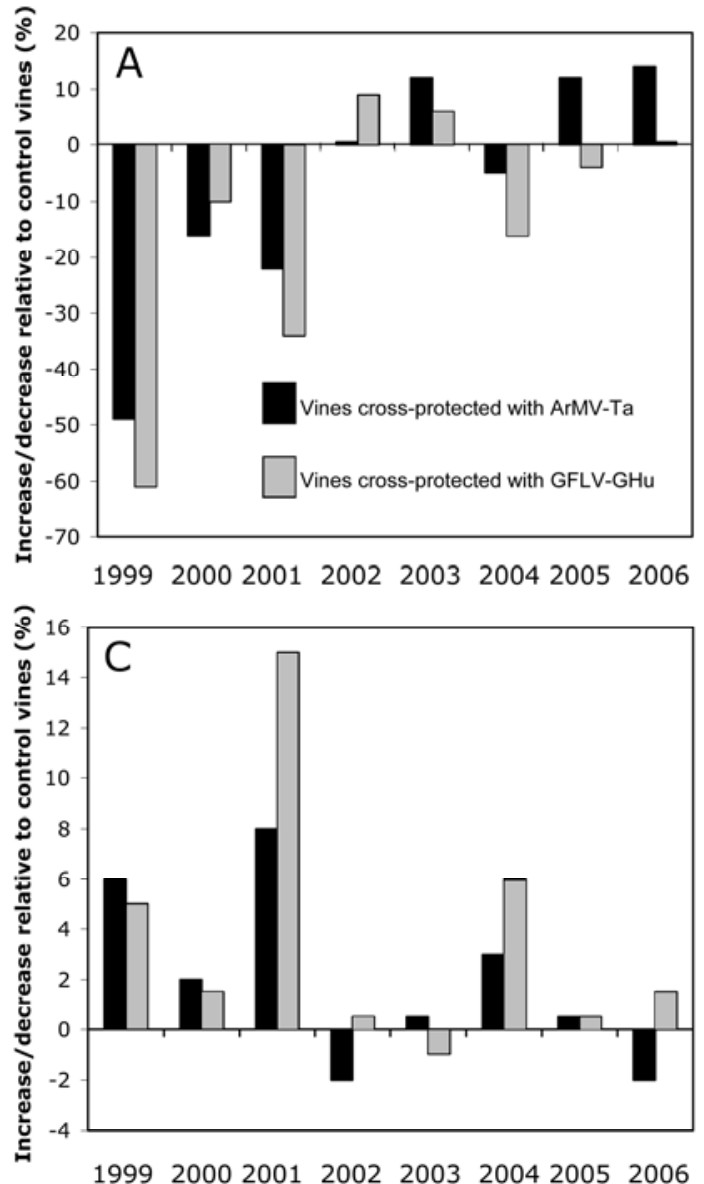
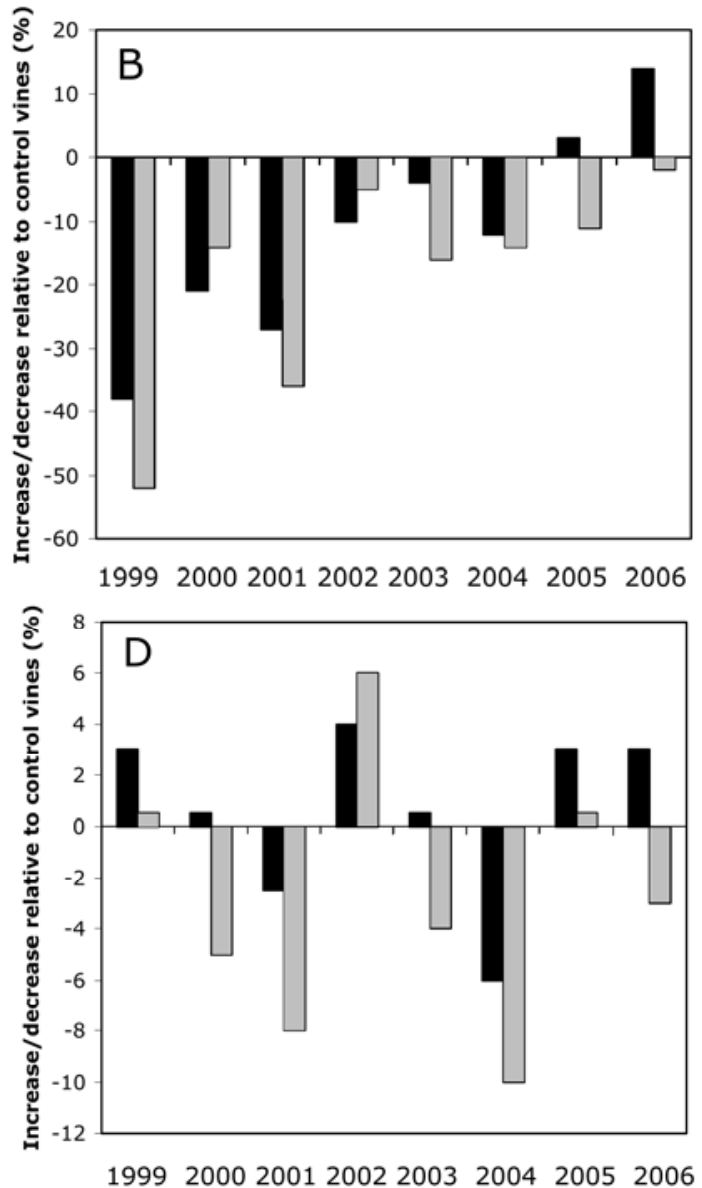

Year

Fig. 3. Effect of cross-protection from 1999 to 2006 in the Bennwihr site on A, fruit yield per vine, B, cluster weight, C, sugar content in fruit juice, and D, fruit juice titratable acidity. Data are expressed as percent increase or decrease relative to control vines for cross-protected vines initially infected with Arabis mosaic virus (ArMV)-Ta or Grapevine fanleaf virus (GFLV)-GHu. 
protected vines was neutral from 1999 to 2006, with no significant differences in LS means $(t$ value $=0.47 ; \mathrm{df}=48 ; P=0.6389$ for ArMV-Ta and $t$ value $=-0.93 ; \mathrm{df}=48$; $P=0.3595$ for GFLV-GHu). Together, cross-protected vines had no impact on titratable acidity in fruit juice, and most of the variation observed was due to seasonal fluctuations.

Genetic stability of the $\mathrm{CP}$ gene of mild protective strains GFLV-GHu and ArMV-Ta. The genetic stability of the 1.5$\mathrm{kb}$ CP gene of mild strains GFLV-GHu and ArMV-Ta was examined over time by ICRT-PCR combined with cloning and sequencing to better characterize the reaction of cross-protected plants to GFLV infection. A $99.5 \%$ nucleotide identity was obtained by comparing the $\mathrm{CP}$ gene nucleotide sequence of ArMV-Ta and GFLV-GHu from vines grown in the greenhouse and in field B over 10 years. These results were consistent with the genetic stability of the $\mathrm{CP}$ gene over a decade. Similar data were reported previously for other GFLV strains (32).

\section{DISCUSSION}

GFLV is widespread in major viticultural regions of the world and causes severe losses (1). It is estimated to affect $65 \%$ of the grape acreage in France (540,000 ha) with a severe incidence in $30 \%$ (270,000 ha) (9). Presently, control strategies against GFLV are not satisfactory. Soil disinfection with nematicides is of limited efficacy to eradicate $X$. index populations (1). In addition, this approach is costly and can also contaminate groundwater supplies and affect nontarget soil microorganisms (1). Rootstocks resistant to $X$. index, in particular VR 039-16 (37) and RS-3 (3), are used in California to mitigate the impact of GFLV. However, this material does not prevent the translocation of GFLV from rootstocks to scions following feeding of viruliferous nematodes, although a severe decline in fruit set does not generally occur in grafted vines (38).

Cross-protection, a phenomenon whereby a mild virus strain can protect plants from challenge infection by a more virulent strain, is an attractive strategy to mitigate the impact of viruses, in particular in perennial crops. It was first described by McKinney in 1929 (24). Success of crossprotection has been documented in citrus against Citrus tristeza virus (8), in cucurbits against Zucchini yellow mosaic virus $(19,21,39)$, and in papaya and cucurbits against Papaya ringspot virus $(27,40,42)$, among others. In the case of nepoviruses, previous studies have shown that herbaceous plants can be protected from infection with severe virus strains $(6,7,11,13$, 15,17,36). Protection against nepoviruses is expressed as delayed challenge infection $(6,11,15,17,36)$, absence of challenge virus symptoms $(7,11,13,36)$, reduced accumula- tion of challenge virus $(7,11,17)$, or inhibition of challenge virus multiplication (17).

In the present work, we examined the ability of two mild virus strains, one of GFLV and one of ArMV, to control GFLV in two naturally infected vineyard sites. Our data demonstrated that those strains significantly reduced infection by challenge GFLV isolates in the two vineyard sites, in particular when GFLV-GHu was used as the protective strain. However, in spite of their protective ability, the two mild strains had a substantial negative impact on fruit yield. Thus, crossprotection with ArMV-Ta and GFLV-GHu appears to be of limited practical interest, if any, to control GFLV because a detrimental impact on production is not attractive to the grape and wine industry.

The fact that a higher protection rate was achieved against GFLV with GFLV$\mathrm{GHu}$ rather than with ArMV-Ta is consistent with cross-protection being more efficient if the protective and challenge virus strains are similar or related $(20,25)$. In contrast, cross-protection is less or not effective if the two virus strains are less related or unrelated $(11,13,15)$. Also, cross-protection often does not work well if the two viruses are inoculated simultaneously (20). For GFLV, 3 to 9 days or 20 days were required for the establishment of cross-protection against challenge strains after the protective strain has infected $C$. quinoa (17) and Gomphrena globosa (6), respectively. This sequential infection is conceivably of practical interest for a perennial crop like grapevine because rootstocks can be infected with a mild strain several months or even years prior to exposure of grafted vines to challenge virus strains in the vineyard.

The mechanism of cross-protection has not been deciphered, in particular for GFLV. Cross-protection was initially ascribed to competition for host factors. Indeed, protective and challenge virus isolates could compete for the same host factors that are indispensable in the virus multiplication cycle $(15,20,25)$. Other studies suggest the implication of a differential spatial distribution and an exclusion mechanism, whereby a plant cell already infected with a virus strain cannot be superinfected by other strains $(20,28,29)$ or by another virus (12). Also, PTGS is active in RNA-mediated cross-protection $(26,43)$. Regardless of the mechanism of crossprotection, the fact that it only occurs between closely related viruses implies that viral nucleotide sequence similarity is required for competition. Our results support this hypothesis because the rate of GFLV infection was markedly lower in vines initially infected with GFLV-GHu (19\%) than in those initially infected with ArMV-Ta (40 to 65\%). Furthermore, if PTGS were active in our cross-protected vines, a high nucleotide sequence identity between the mild protective and challenge virus strains would be expected for efficient RNA degradation. Since GFLV-GHu is an interspecies recombinant between GFLV and ArMV with part of the RNA2encoded $2 \mathrm{~A}^{\mathrm{HP}}$ and $2 \mathrm{~B}^{\mathrm{MP}}$ genes of ArMV origin and the $2 \mathrm{C}^{\mathrm{CP}}$ gene of GFLV origin (34), it is conceivable that the CP gene might be involved in the protective mechanism. However, more work is needed to validate this hypothesis.

The CP gene of mild strain ArMV-Ta, as well as of GFLV-GHu, was genetically stable over the course of the crossprotection trial in the Bennwihr site, as shown by comparative sequence data. Therefore, natural mutations in this viral gene that could have precluded protection of test plants are unlikely to account for a high infection rate of vines cross-protected with ArMV-Ta. Instead, monitoring the accumulation of the protective strain ArMV-Ta over time indicated a drastic reduction in ArMV 13 years postplanting in the Ammerschwihr site (from $100 \%$ to $65 \%$ of the cross-protected vines) and 11 years postplanting in the Bennwihr site (from 100 to $36 \%$ of the cross-protected vines). This reduction could result from a displacement of ArMV-Ta by indigenous GFLV strains, as shown previously in $C$. quinoa (17), maybe as a result of poor competitiveness of the mild protective strain. Although at a lower extent, a similar lower level of GFLV-GHu was observed 11 years after planting by IC-RT-PCR-RFLP in a few cross-protected vines $(4 \%, 4$ of 100) in the Bennwihr site.

Mild protective strains GFLV-GHu and ArMV-Ta were isolated from field infected vines, and subsequently were propagated and selected on C. quinoa $(17,22)$. These strains could be engineered for improved cross-protection potential by reducing their pathogenicity and increasing their competitiveness. For viruses different from GFLV, treating virions with mutagenic agents (41) or low temperature (19), or mutagenizing full-length cDNA clones of genomic viral RNA $(23,42)$ are other approaches used to develop mild protective strains. For GFLV, variants with reduced virulence and increased competitiveness could be engineered from full-length infectious cDNA clones (35) by reverse genetics and mutagenesis. GFLV cDNA clones have been successfully used to unravel GFLV$X$. index interactions (2), cell-to-cell and long distance movement, and processing of the RNA2-encoded polyprotein $(4,5)$ as well as determining the biological properties of recombinant variants (32). They could be further used to engineer a mild protective chimeric GFLV strain for improved cross-protection potential, as described for a cucumovirus (43) and potyviruses $(23,42)$.

\section{ACKNOWLEDGMENTS}

This work was partially supported by a competitive grant from the European Commission (Envi- 
ronmental impact assessment of the transgenic grapevines and plums on the diversity and dynamics of virus populations, QLK3-CT-2002-02140). We are grateful to Michel Fonné and François Klur for providing experimental GFLV-infected vineyard sites, and to Peggy Andret-Link, Catherine Reinbold, Monique Beuve, Marlène Henry, Anne Marie Chanel, Pascal Cornuet, Charles Greif, and Etienne Herrbach for assistance at harvest. We are indebted to John Barnard for advice with statistical analyses and to L. M. Yepes for critically reading the manuscript.

\section{LITERATURE CITED}

1. Andret-Link, P., Laporte, C., Valat, L., Laval, V., Ritzenthaler, C., Demangeat, G., Vigne, E., Pfeiffer, P., Stussi-Garaud, C., and Fuchs, M. 2004. Grapevine fanleaf virus: Still a major threat to the grapevine industry. J. Plant Pathol. 86:183-195.

2. Andret-Link, P., Schmitt-Kechinger, C., Demangeat, G., Komar, V., and Fuchs, M. 2004. The specific transmission of Grapevine fanleaf virus by its nematode vector Xiphinema index is solely determined by the viral coat protein. Virology 320:12-22.

3. Anwar, S. A., McKenry, M., and Ramming, D. 2002. A search for more durable grape rootstocks resistance to root-knot nematode. Am. J. Enol. Vitic. 53:19-23.

4. Belin, C., Schmitt, C., Demangeat, G., Komar, V., Pinck, L., and Fuchs, M. 2001. Involvement of RNA2-encoded proteins in the specific transmission of Grapevine fanleaf virus by its nematode vector Xiphinema index. Virology 291:161-171

5. Belin, C., Schmitt, C., Gaire, F., Walter, B., Demangeat, G., and Pinck, L. 1999. The nine C-terminal residues in grapevine fanleaf nepovirus movement protein are critical for systemic virus spread. J. Gen. Virol. 80:13471356.

6. Bianco, P. A., Bruno, I., Fortusini, A., and Belli, G. 1988. Cross-protection tests on herbaceous hosts with Grapevine fanleaf virus (GFLV). Riv. Patol. Vege. 24:81-88

7. Bitterlin, M. W. 1986. Tomato ringspot virus: Interations with its nematode vector Xiphinema rivesi, studies on virus transmission to and detection in fruit trees, serological characterization and implications for cross protection. Ph.D. diss. Cornell University, Ithaca, NY. p. 156.

8. Costa, A. S., and Muller, G. W. 1977. Tristeza control by cross protection: A U.S. Brazil cooperative success. Plant Dis. 64:538-541.

9. Demangeat, G., Esmenjeaud, D., Voisin, R., Bidault, J.-M., and Claverie, M. 2005. Le court -noué de la vigne: Etat des connaissances sur cette maladie. Phytoma 587:38-42.

10. Demangeat, G., Voisin, R., Minot, J.-C., Bosselut, N., Fuchs, M., and Esmenjaud, D. 2005. Survival of Xiphinema index in vineyard soil and retention of Grapevine fanleaf virus over extended time in the absence of host plants. Phytopathology 95:1151-1156.

11. Dias, H. F., and Harrison, B. D. 1978. The relationship between grapevine fanleaf, grapevine yellow mosaic, and arabis mosaic viruses. Ann. Appl. Biol. 51:97-105.

12. Dietrich, C., and Maiss, E. 2003. Fluorescent labelling reveals spatial separation of potyvirus populations in mixed infected Nicotiana benthamiana plants. J. Gen. Virol. 84:2871-2876.
13. Doz, B., Delbos, R., and Dunez, J. 1982. Prémunition: Une compétition entre souches faibles et souches sévères pour une voie commune d'expression de symptômes. Colloques de l'INRA 11:29-44.

14. Fuchs, M., Ferreira, S., and Consalves, D. 1997. Management of virus diseases by classical and engineered protection. Mol. Plant Pathol. Online: http://www.bspp.org.uk/mppoll 1997/0116fuchs

15. Fulton, R. W. 1975. Unilateral cross protection among some nepoviruses. Acta Hortic. 44:2932.

16. Hall, J. S., French, R., Hein, G. L., Morris, T. J., and Stenger, D. C. 2001. Three distinct mechanisms facilitate genetic isolation of sympatric wheat streak mosaic virus lineages. Virology 282:230-236.

17. Huss, B., Walter, B., and Fuchs, M. 1989. Cross-protection between arabis mosaic virus and grapevine fanleaf vius isolates in Chenopodium quinoa. Ann. Appl. Biol. 114:45-60.

18. Komar, V., Vigne, E., Demangeat, G., and Fuchs, M. 2007. Beneficial effect of selective virus elimination on the performance of Vitis vinifera cv. Chardonnay. Am. J. Enol. Vitic. 58:202-210.

19. Kosaka, Y., Ryang, B.-S., Kobori, T., Shiomi, H., Yasuhara, H., and Kataoka, M. 2006. Effectiveness of an attenuated Zucchini yellow mosaic virus isolate for cross-protecting cucumber. Plant Dis. 90:67-72.

20. Lecoq, H. 1998. Control of plant virus diseases by cross-protection. Pages 33-40 in: Plant Virus Disease Control. A. Hadidi, R. K. Khetarpal, and H. Koganezawa, eds. American Phytopathological Society, St. Paul, MN.

21. Lecoq, H., Lemaire, J. M., and Wipf-Scheibel, C. 1991. Control of Zucchini yellow mosaic virus in squash by cross protection. Plant Dis. 75:208-211.

22. Legin, R., Bass, P., Etienne, L., and Fuchs, M. 1993. Selection of mild virus strains of fanleaf degeneration by comparative field performance of infected grapevines. Vitis 32:103-110.

23. Lin, S.-S., Wu, H.-W., Jan, F.-J., Hou, R. F., and Yeh, S.-D. 2007. Modifications of the helper component-protease of Zucchini yellow mosaic virus for generation of attenuated mutants for cross protection against severe infection. Phytopathology 97:287-296.

24. McKinney, H. H. 1929. Mosaic diseases in the Canary islands, west of Africa and Gibraltar. J. Agric. Res. 39:557-578.

25. Muller, G. W., and Rezende, J. A. M. 2004. Preimmunization: Application and Perspectives in Viral Disease Control. Pages 361-396 in: Diseases of Fruits and Vegetables, Diagnosis and Management. S. A. M. H. Naqvi, ed. Kluwer Academic Publishers, Dordrecht, Netherlands.

26. Ratcliff, F. G., MacFarlane, S. A., and Baulcombe, D. C. 1999. Gene silencing without DNA: RNA-mediated cross-protection between viruses. Plant Cell 11:1207-1215.

27. Rezende, J. A. M., and Pacheco, D. A. 1998. Control of Papaya ringspot virus - type $\mathrm{W}$ in zucchini squash by cross-protection in Brazil. Plant Dis. 82:171-175.

28. Takahashi, T., Sugawara, T., Yamatsuta, T., Isogai, M., Natsuaki, T., and Yoshikawa, N. 2007. Analysis of the spatial distribution of identical and two distinct virus populations differently labeled with cyan and yellow fluores- cent proteins in coinfected plants. Phytopathology 97:1200-1206.

29. Takeshita, M., Shigemune, N., Kikuhara, K. Furuya, N., and Takanami, Y. 2004. Spatial analysis for exclusive interactions between subgroups I and II of Cucumber mosaic virus in cowpea. Virology 328:45-51.

30. Thompson, J. D., Higgins, D. G., and Gibson, T. J. 1994. CLUSTAL W: Improving the sensitivity of progressive multiple sequence alignment through sequence weighting, positionspecific gap penalties and weight matrix choice. Nucleic Acids Res. 22:4673-4680.

31. Vigne, E., Bergdoll, M., Guyader, S., and Fuchs, M. 2004. Population structure and genetic diversity within Grapevine fanleaf virus isolates from a naturally infected vineyard: Evidence for mixed infection and recombination. J. Gen. Virol. 85:2435-2445.

32. Vigne, E., Demangeat, G., Komar, V., and Fuchs, M. 2005. Characterization of a naturally occurring recombinant isolate of Grape vine fanleaf virus. Arch. Virol. 150:2241-2255.

33. Vigne, E., Komar, V., and Fuchs, M. 2004. Field safety assessment of recombination in transgenic grapevines expressing the coat protein gene of Grapevine fanleaf virus. Transgenic Res. 13:165-179.

34. Vigne, E., Marmonier, A., and Fuchs, M. 2008. Multiple interspecies recombination events between Grapevine fanleaf virus and Arabis mosaic virus. Arch. Virol. 153:1771-1776.

35. Viry, M., Serghini, M. A., Hans, F., Ritzenthaler, C., Pinck, M., and Pinck, L. 1993. Biologically active transcripts from cloned cDNA of genomic grapevine fanleaf nepovirus RNAs. J. Gen. Virol. 74:169-174.

36. Vuittenez, A., Kuszala, J., Legin, R., Stocky, G., Pejcinovski, P., and Heyd, C. 1976. Phénomènes d'interaction entre souches de virus nepo infectant la vigne. Proc. 6th International Council of ICVG, Monografias, INIA. 18:5968.

37. Walker, M. A., Lider, L. A., Goheen, A. C., and Olmo, H. P. 1991. VR 039-16 grape rootstock. HortScience 26:1224-1225.

38. Walker, M. A., Wolpert, J. A., and Weber, E. 1994. Field screening of grape rootstock selections for resistance to fanleaf degeneration. Plant Dis. 78:134-136.

39. Walkey, D. G. A., Lecoq, H., Collier, R., and Dobson, S. 1992. Studies on the control of Zucchini yellow mosaic virus in courgettes by mild strain protection. Plant Pathol. 41:762 771.

40. Wang, H. L., Yeh, S. D., Chiu, R. J., and Gonsalves, D. 1987. Effectiveness of crossprotection by mild mutants of papaya ringspot virus for control of ringspot disease of papaya in Taiwan. Plant Dis. 71:491-497.

41. Yeh, S.-D., and Gonsalves, D. 1984. Evaluation of induced mutants of papaya ringspot virus for control by cross protection. Phytopathology 74:1086-1091.

42. You, B.-J., Chiang, C.-H., Chen, L.-F., Su, W. C., and Yeh, S.-D. 2005. Engineered mild strains of Papaya ringspot virus for broader cross protection in cucurbits. Phytopathology 95:533-540.

43. Ziebell, H., Payne, T., Berry, J. O., Walsh, J. A., and Carr, J. P. 2007. A Cucumber mosaic virus mutant lacking the $2 \mathrm{~b}$ counter-defence protein gene provides protection against wildtype strains. J. Gen. Virol. 88:2862-2871. 